\title{
UPAYA MENINGKATKAN HASIL BELAJAR MATEMATIKA PADA MATERI PECAHAN DENGAN MENGGUNAKAN PEMBELAJARAN KOOPERATIF TIPE SNOWBALL THROWING KELAS IV SDN 168060 KOTA TEBING TINGGI
}

\author{
Nurhaida Lubis
}

Surel: nurhaida@gmail.com

\begin{abstract}
Mathematical learning using snowball Throwing cooperative learning can improve learning outcomes of fourth grade students of SD Negeri 168060 Tebing Tinggi in 2014/2015 academic year in the ability to understand fraction material This can be seen from the increase in students' ability to understand fraction material from the pre test results in pre the cycle where the average acquisition of grade IV students is 56.87 with the percentage of completeness class $25 \%$. In the first cycle it increased with a class average of 64.37 and a percentage of completeness of $62.5 \%$. While in the second cycle the class average reached 81.56 with the percentage of students completing $93.7 \%$. From the results of these tests it can be concluded that this research can be said to be successful.
\end{abstract}

Keywords: Learning Outcomes, Snowball Throwing, Fractions

\begin{abstract}
ABSTRAK
Pembelajaran matematika dengan menggunakan pembelajaran kooperatif tipe snowball Throwing dapat meningkatkan hasil belajar siswa kelas IV SD Negeri 168060 kota Tebing Tinggi Tahun Pelajaran 2014/2015 dalam kemampuan memahami materi pecahan Hal Ini dapat dilihat dari peningkatan kemampuan siswa dalam memahami materi pecahan dari hasil pre tes pada pra siklus dimana rata rata perolehan siswa siswa kelas IV adalah 56,87 dengan persentase ketuntasan kelas 25\%. Pada siklus I meningkat dengan rata-rata kelas 64,37 dan persentase ketuntasan 62,5\%. Sedangkan pada siklus II rata-rata kelas mencapai 81,56 dengan persentase ketuntasan siswa 93,7\%. Dari hasil tes tersebut dapat diambil kesimpulan bahwa penelitian ini dapat dikatakan berhasil.
\end{abstract}

Kata Kunci: Hasil Belajar, Snowball Throwing, Pecahan

\section{PENDAHULUAN}

Pendidikan merupakan sebuah aktivitas yang sangat penting dalam upaya pengembangan sumber daya manusia dan merupakan kebutuhan dasar bagi seluruh lapisan masyarakat Indonesia yang ingin maju. Pendidikan pada masa sekarang ini semakin tergantung pada tingkat kualitas, Guru SDN 168060 Kota Tebing Tinggi antismatematikasi dari para guru untuk menggunakan berbagai sumber yang tersedia, dalam upaya mengatasi permasalahan yang dihadapi siswa untuk mempersiapkan pembelajaran yang dapat menumbuhkan cara berfikir siswanya menjadi lebih kritis dan kreatif. Namun, di sisi lain perkembangan 
pendidikan menghadapi kenyataan yang sangat memprihatinkan bahwa minat dan motivasi belajar siswa yang sangat kurang. Mata pelajaran matematika merupakan satu mata pelajaran dari lima mata pelajaran pokok yang diajarkan pada tingkat sekolah dasar (SD). Pada kenyataannya sebagian besar peserta didik terutama di tingkat sekolah dasar kurang menyenangi pelajaran matematika tersebut. Alasan siswa sekolah dasar kurang menyenangi dan termotivasi untuk mengikutinya disebabkan mata pelajaran matematika sangat sulit untuk dmatematikahami karena sebagian besar materinya bersifat abstrak, memerlukan penalaran yang sangat baik agar mengerti, sehingga siswa kurang berminat untuk mengikuti pelajaran ini. Selain itu siswa merasa bahwa pembelajaran matematika yang diberikan oleh guru selama ini kurang menarik, monoton dan tidak variatif pada kegiatan pembelajarannya. Idealnya pembelajaran matematika di SD diajarkan melalui: melihat, mendengar, membaca, mengikuti perintah, mengimitasi, mempraktekan, dan menyelesaikan latihan. Pengalaman akan bendabenda kongkrit yang dimiliki anak sangat membantu dalam mendasari pemahaman konsep-konsep yang abstrak. Guru harus terampil membangun jembatan penghubung antara pengalaman kongkrit dengan konsep-konsep matematika.
Pembelajaran matematika di sekolah dasar pada umumnya dilakukan oleh guru dengan mengenalkan rumus-rumus dan konsep-konsep secara verbal, tanpa ada perhatian yang khusus terhadap pemahaman siswa secara konkrit. Disamping itu proses belajar mengajar selalu menggunakan metode "chalk and talk " guru yang menjadi pusat aktifitas dan kegiatan di dalam kelas. Selain apa yang dinyatakan di atas, faktor lain yang menyebabkan pelajaran matematika itu sulit dmatematikahami oleh siswa adalah siswa kurang memiliki pengetahuan prasyarat serta kurang mengetahui apakah manfaatnya belajar matematika bagi meraka sehingga keinginan untuk mempelajari matematika itu tidak muncul pada diri mereka. Faktor yang lain adalah daya abstraksi siswa kurang dalam memahami konsep konsep matematika yang bersifat abstrak. Berdasarkan hasil ujian formatif maupun ulangan harian yang dilakukan peneliti sebagai seorang guru di SD Negeri 168060 Jalan Gunung Arjuna, Kecamatan Rambutan, Kota Tebing Tinggi, terlihat materi pecahan merupakan materi dalam pelajaran matematika yang sangat sulit dmatematikahami oleh siswa jika dibandingkan dengan beberapa materi lain. Hal ini sangat terlihat ketika siswa diminta untuk menjumlahkan, mengurangkan, membagi dan mengalikan pecahan, baik pecahan yang sama penyebut maupun yang berbeda penyebut terlihat sekali siswa kelas IV sangat 
mengalami kendala. Dari 16 orang siswa kelas IV hanya 4 siswa (25\%) yang dapat mengerjakannya, selebihnya sebanyak 12 siswa (75\%) masih belum dapat mengerjakannya. Kondisi pembelajaran yang demikian tentunya tidak boleh dibiarkan dan harus segera dicarikan solusinya, agar pembelajaran matematika menjadi lebih mudah dmatematikahami, lebih menarik bagi siswa, sehingga siswa menjadi lebih termotivasi untuk belajar matematika, lebih senang belajar matematika dan berujung pada hasil pembelajaran matematika yang meningkat. Selain itu hasil kemampuan siswa dalam matematika tersebut dapat diimplementasikannya langsung didalam kehidupannya sehari-hari. Dalam mengajar matematika, seorang guru tidak hanya berkewajiban sekedar menyampaikan materi agar selesai saja, namun juga diwajibkan memikirkan dan merancang sebuah proses pembelajaran yang dapat membangkitkan motivasi siswa untuk ikut dalam proses pembelajaran sehingga mampu mengasah keterampilan dan kemampuan yang ada pada diri mereka masing masing. Salah satu cara yang bisa dilakukan guru adalah dengan merancang pembelajaran dengan menggunakan berbagai metode dan pendekatan yang menarik bagi siswa. Pembelajaran dengan menggunakan model pembelajaran kooperatif merupakan salah satu pilihan yang dapat dilakukan oleh guru dalam mengajarkan matematika. Pembelajaran kooperatif tipe Snowball Throwing merupakan salah satu model pembelajaran yang dapat diterapkan dalam upaya meningkatkan hasil belajar matematika. Pembelajaran kooperatif tipe Snowball Throwing akan memberikan kebebasan kepada siswa untuk berlatih mengerjakan soal-soal yang berhubungan dengan pecahan, tanpa ada tekanan dan takut ketika berbuat salah. Pembelajaran kooperatif tipe Snowbal Throwing akan memberikan kepercayaan diri siswa dalam belajar matematika. Dengan menggunakan pembelajaran kooperatif tipe Snowball Throwing diharapkan semangat dan motivasi siswa akan timbul untuk mengikuti pembelajaran, sehingga hasil belajar matematika menjadi lebih meningkat.

Berdasarkan latar belakang dan paparan di atas, peneliti tertarik untuk melakukan penelitian pada mata pelajaran matematika dengan judul : " Upaya meningkatkan hasil belajar matematika pada materi pecahan dengan menggunakan pembelajaran kooperatif tipe Snowball Throwing siswa kelas IV SD Negeri 168060 kota Tebing Tinggi tahun pembelajaran 2014/ 2015 “.

\section{Identifikasi Masalah}

Berdasarkan latar belakang masalah dan beberapa faktor yang mempengaruhi hasil belajar siswa 
pada pelajaran matematika dapat diidentifikasi seperti berikut: Rendahnya hasil belajar siswa pada pelajaran matematika Metode pembelajaran yang digunakan guru kurang bervariasi, Siswa menganggap pelajaran matematika itu sulit dan membingungkan, dan Kurang tepatnya pendekatan atau model pembelajaran yang dipilih oleh guru.

\section{Pembatasan Masalah}

Mengingat keterbatasan kemampuan, waktu, dana, dan untuk lebih fokus melakukan penelitian ini, peneliti perlu membatasi masalah penelitiannya pada peningkatan hasil belajar matematika pada materi pecahan dengan menggunakan pembelajaran kooperatif tipe Snowball Throwing siswa kelas IV SD Negeri 168060 kota Tebing Tinggi.

\section{Rumusan Masalah}

Berdasarkan identifikasi masalah dan pembatasan masalah di atas, maka yang menjadi rumusan masalah dalam penelitian ini adalah: "Apakah dengan menggunakan pembelajaran kooperatif tipe Snowball Throwing dapat meningkatkan hasil belajar Matematika materi pecahan siswa kelas IV SD Negeri 168060 kota Tebing Tinggi tahun pelajaran 2014/ 2015 ?"

\section{Tujuan Penelitian}

Tujuan penelitian yang akan dicapai dalam penelitian ini adalah: Untuk meningkatkan hasil belajar matematika pada materi pecahan dengan menggunakan pembelajaran kooperatif tipe Snowball Throwing siswa kelas IV SD Negeri 168060 kota Tebing Tinggi tahun pembelajaran 2014/ 2015.

\section{Manfaat Penelitian}

Penelitian ini diharapkan dapat bermanfaat sebagai berikut :

Bagi Siswa

- $\quad$ Penelitian ini bermanfaat bagi siswa karena dapat meningkatkan hasil belajar matematika pada materi pecahan

- Membantu siswa berfikir kritis, rasional dan kreatif dan dapat memperoleh informasi dan pengalaman langsung melalui kegiatan bermain

- Memberi peluang kepada siswa untuk lebih aktif mengembangkan potensi dirinya terutama dalam memberi pendapatpendapat yang konstruktif positif untuk memecahkan masalah dalam kehidupannya sehari-hari

Manfaat Bagi Guru

- Meningkatkan kualitas guru dalam melaksanakan tugas mengajar terutama dalam mengajar matematika.

- $\quad$ Merangsang guru-guru yang lain untuk melakukan pembelajaran yang kreatif dan menyenangkan bagi siswa.

Manfaat Bagi Sekolah 
- Meningkatkan hasil belajar matematika di SD Negeri 168060 kota Tebing Tinggi, sehingga mampu bersaing dengan sekolah sekolah yang lain..

- $\quad$ Penelitian ini bermanfaat bagi sekolah karena dapat memberi masukan atau sumbangan penelitian bagi peneliti lain yang melakukan Penelitian Tindakan Kelas (PTK).

\section{METODE PENELITIAN Subjek Penelitian}

Subjek pada penelitian ini adalah siswa kelas IV SD Negeri 168060 kota Tebing Tinggi yang beralamat di Jalan Gunung Arjuna, Kecamatan Rambutan, Kota Tebing Tinggi tahun pelajaran 2014/2015 yang berjumlah 16 siswa, dengan jumlah siswa lakilaki 9 orang dan jumlah siswa perempuan 7 orang. Rata rata usia siswa antara 9-10 tahun.

\section{Tempat dan waktu penelitian}

Penelitian ini dilakukan di SD Negeri 168060 yang beralamat di Jalan Gunung Arjuna, Kecamatan Rambutan, Kota Tebing Tinggi. Penelitian ini dilakukan pada semester dua ( genap ) tahun pembelajaran 2014/2015 yaitu bulan Januari sampai dengan Mei 2015.

\section{Desain penelitian}

Desain penelitian dalam penelitian tindakan kelas berupa refleksi awal dan observasi untuk mengidentifikasi permasalahan yang terjadi di kelas, dilanjutkan dengan pelaksanaan PTK selama dua siklus. Desain penelitian menggunakan penelitian tindakan kelas dengan model yang dikemukakan oleh Arikunto (2006 : 16).

\section{Prosedur Penelitian}

Penelitian ini langsung dilakukan di dalam kelas yang meliputi kegiatan pelaksanaan PTK berupa refleksi awal dan observasi untuk mengidentifikasi permasalahan yang terjadi dalam kelas. Pada penelitian ini, peneliti akan dibantu oleh seorang guru kelas yang mengidentifikasi dan mencari pemecahan masalah pembelajaran dalam mata pelajaran matematika kelas IV SD Negeri 168060 kota Tebing Tinggi.Sebelum melaksanakan penelitian, peneliti terlebih dahulu memberikan tes awal kepada siswa kelas IV yang bertujuan untuk mengetahui kemampuan awal siswa. Maka akan dilakukan penelitian tindakan kelas dengan prosedur yang disusun oleh Arikunto (2006 : 16) yang terdiri dari 4 tahapan, yaitu 1) perencanaan, 2) pelaksanaan, 3) pengamatan, dan 4) refleksi. Pelaksanaan penelitian ini direncanakan dalam 2 siklus dalam setiap siklus ada 2 kali pertemuan sehingga dari dua siklus ada 4 kali pertemuan dimana setiap siklus dilaksanakan sesuai dengan perubahan yang ingin dicapai.

\section{Indikator Keberhasilan}

$$
\text { Indikator keberhasilan }
$$

penelitian ini adalah apabila rata rata presentase hasil tes siswa mencapai $85 \%$ siswa dari seluruh jumlah siswa yang menjadi sampel pada penelitian ini.

\section{HASIL DAN PEMBAHASAN}

Dapat dilihat bahwa kemampuan siswa dalam memahami materi pecahanberdasarkan hasil tes 
yang dilakukan setelah siklus I selesai dilaksanakan sudah makin meningkat jika dibandingkan dengan hasil perolehan nilai pada kegiatan pra siklus. Jika pada pra siklus jumlah siswa yang berada pada interval nilai $\leq 49$ berjumlah 4 siswa (25\%) maka pada siklus I sudah tidak ada lagi siswa yang berada pada interval tersebut. Untuk interval nilai 50-59 jika pada pra siklus berjumlah 3 siswa $(18,75 \%)$ maka pada siklus I berkurang hanya menjadi 1 siswa $(6,25 \%)$, untuk interval nilai 60-69 jika pada pra siklus ada 5 siswa ( $31,25 \%$ ) maka pada siklus I masih tetap 5 siswa ( $31,25 \%$ ), interval 70 79 jika pada pra siklus hanya ada 2 siswa yang memperolehnya ( $12,5 \%)$ maka pada siklus I terjadi peningkatan dimana sebanyak 5 siswa $\quad(31,25 \%) \quad$ sudah memperolehnya, interval 80-89 jika pada pra siklus hanya 2 siswa $(12,5 \%)$ maka pada siklus I meningkat menjadi 4 siswa (25\%) dan interval nilai yang terakhir yaitu rentang 90 - 100 jika pada pra siklus tidak ada siswa satu orangpun yang memperoleh nilai itu maka pada siklus I ada 1 siswa $(6,25 \%)$ yang memperolehnya.

Dari data di atas terlihat kemampuan siswa meningkat setelah guru mengajar matematika dengan menggunakan model pembelajaran kooperatif snowball throwing. Hal ini juga bisa kita lihat pada persentase pencapaian secara klasikal terhadap KKM yang telah ditentukan. Jika pada kegiatan pra siklus pencapaian presentase secara klasikal hanya mencapai $25 \%$ maka pada siklus I telah mencapai $62,5 \%$ terjadi peningkatan sekitar $37,5 \%$ jika dibandingkan dengan pra siklus.
Berdasarkan hasil tes yang dilakukan setelah siklus II selesai dilaksanakan sudah makin meningkat jika dibandingkan dengan hasil perolehan nilai pada kegiatan pada siklus I. Jika pada siklus I jumlah siswa yang berada pada interval nilai 50-59 berjumlah siswa $(6,25 \%)$ maka pada siklus II sudah tidak ada lagi siswa yang berada pada interval nilai tersebut, untuk interval nilai 60-69 jika pada siklus I ada 5 siswa ( $31,25 \%)$ maka pada siklus II sudah berkurang menjadi 1 siswa (6,25\%), interval 80-89 jika pada siklus I ada 2 siswa (12,5\%) maka pada siklus II sudah meningkat menjadi 7 siswa ( $43,75 \%$ ) dan interval nilai $90-100$ jika pada siklus I tdak ada siswa yang memperoleh nilai tersebut, maka pada siklus II untuk interval 90-100 ada 5 siswa $(31,25 \%)$ yang sudah memperolehnya.

Dari data di atas terlihat kemampuan siswa meningkat setelah guru mengajar matematika dengan menggunakan model pembelajaran kooperatif snowball throwing. Hal ini juga bisa kita lihat pada persentase pencapaian secara klasikal terhadap KKM yang telah ditentukan. Jika pada kegiatan siklus I pencapaian presentase secara klasikal hanya mencapai $25 \%$ maka pada siklus II telah mencapai $93,7 \%$ terjadi peningkatan sekitar $68,7 \%$ jika dibandingkan dengan siklus II.

\section{Pembahasan}

Pada tahap persiapan penelitian, peneliti menganalisis kondisi yang 
bertujuan untuk mengetahui ketersediaan alat dan bahan pembelajaran, kondisi kelas dan jumlah subjek penelitian. Media pembelajaran yang berkaitan dengan materi yang akan peneliti berikan ternyata cukup tersedia. Pada awal pertemuan sebelum siklus I dilaksanakan, peneliti melakukan pretes yang bertujuan untuk mengetahui kemampuan awal siswa sebelum penelitian dimulai. Nilai rata-rata pretes siswa pada mata pelajaran matematika materi pecahan adalah 56,87 dengan persentase $25 \%$. Nilai yang diperoleh siswa pada hasil pretes pra siklus ini sangat rendah, hal ini disebabkan karena siswa belum diberikan materi pelajaran matematika dengan menggunakan model pembelajaran kooperatif snowball throwing. Setelah diperoleh kemampuan awal siswa selanjutnya dilakukan pembelajaran yang terdiri dari dua siklus selama dua pertemuan. Selanjutnya pelaksanaan kegiatan belajar mengajar (KBM) dilaksanakan sesuai dengan model pembelajaran kooperatif snowball throwing yang telah dirancang oleh peneliti. Berdasarkan deskripsi yang telah dirancang dalam penelitian maka kegiatan belajar mengajar (KBM) pada siklus I dilakukan dengan menekankan pada materimateri yang berkaitan dengan pecahan dengan menggunakan model pembelajaran kooperatif snowball throwing dalam kelompok besar. Setelah siklus I dilakukan, di akhir siklus I diberikan postes kepada siswa. Hasil postes pada siklus I diperoleh nilai rata-rata siswa 64,37 Presentase ketuntasan belajar siswa pada siklus I sebesar 62,5\%, hal ini belum mencapai kriteria ketuntasan secara klasikal maka penelitian ini dilanjutkan pada siklus II. Siklus II dilaksanakan juga dengan menggunakan model pembelajaran kooperatif snowball throwing. Perbedaan yang terlihat pada siklus II ialah pada kegiatan pembelajarannya dalam melaksanakan model pembelajaran kooperatif snowball throwing, siswa didudukkan secara berpasangan. Tujuannya adalah agar dalam melaksanakan tugas yang diberikan oleh guru, siswa bisa menjadi lebih focus lagi dalam melaksanakan tugas yang diberikan dengan pasangan masing-masing. Model yang diterapkan guru ini sangat berhasil, hal ini dapat dilihat dari hasil yang diperoleh pada siklus II ini nilai rata-rata hasil belajar siswa sebesar 81,56 dengan presentase ketuntasan belajar siswa pada siklus II sebesar 93,7\% dan mencapai kriteria ketuntasan klasikal. Dari hasil siklus II ini dapat diperoleh kesimpulan bahwa dengan menggunakan model pembelajaran kooperatif snowball throwing dapat meningkatkan hasil belajar matematika khususnya pada materi pecahan. Berdasarkan hasil tes yang diperoleh pada siklus II maka penelitian ini tidak perlu dilanjutkan lagi pada siklus berikutnya. 


\section{SIMPULAN}

Dari hasil penelitian ini dapat diambil kesimpulan sebagai berikut:

1. Pembelajaran dengan menggunakan pembelajaran kooperatif tipe snowball throwing dapat meningkatkan hasil belajar pada pembelajaran matematika materi pecahan siswa kelas IV SD Negeri 168060 kota Tebing Tinggi tahun pembelajaran 2014/2015..

2. Peningkatan hasil belajar pada pelajaran matematika materi pecahandapat dilihat dari hasil pre tes pada pra siklus dimana rata rata perolehan siswa siswa kelas IV adalah 56,87 dengan persentase ketuntasan kelas 25\%. Pada siklus I meningkat dengan rata-rata kelas 64,37 dan persentase ketuntasan $62,5 \%$. Sedangkan pada siklus II rata-rata kelas mencapai 81,56 dengan persentase ketuntasan siswa $93,7 \%$.

\section{DAFTAR RUJUKAN}

Arikunto, 2008. Penelitian Timdakam Kelas. Jakarta: PT. Bumi Aksara

Rusman, 2011. Model-model Pembelajaran

Mengembangkan

Profesionalisme

Guru.

Jakarta: PT. Raja Grafindo Persada.

Sardiman, A.M. Interaksi dan Motivasi Belajar Mengajar. Cet. IV; Jakarta: Rajawali Pers. 1992.
Slameto, 2010. Belajar \& FaktorFaktor yang Mempengaruhinya. Jakarta: Rineka Cipta.

Slameto. Belajar dan Faktor-faktor yang Mempengaruhinya. Cet. II; Jakarta: Rineka Cipta. 2005.

Suprijono, Agus, 2009. Cooperative Learning Teori dan Aplikasi Paikem. Surabaya : Pustaka Pelajar.

Syaodih dan Sumantri (2004) Pembahasan Pembelajaran di SD. Jakarta: Universitas Terbuka.

Nasution, S. Berbagai Pendekatan dalam Proses Belajar Mengajar. Cet. IV; Jakarta. PT. Bina Aksara. 2008

Nadzir

(http://dindaachmad.blogspot. com/2011/03/artikel.html. 2 Maret 2011

Sharkey, B.J. 2003. Fitness And Health. Alih bahasa Kebugaran dan Kesehatan oleh: Eri Desmarini Nasution. Jakarta: PT. Raja

Grafindo Persada.Suharsimi Arikunto. 2002. Prosedur Penelitian Suatu Pendekatan Praktek. Jakarta : Rineka Cipta. 